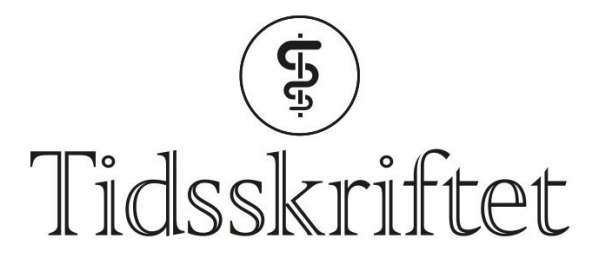

DEN NORSKE LEGEFORENING

\title{
Hverdagsmedisin og hverdagsfotografi
}

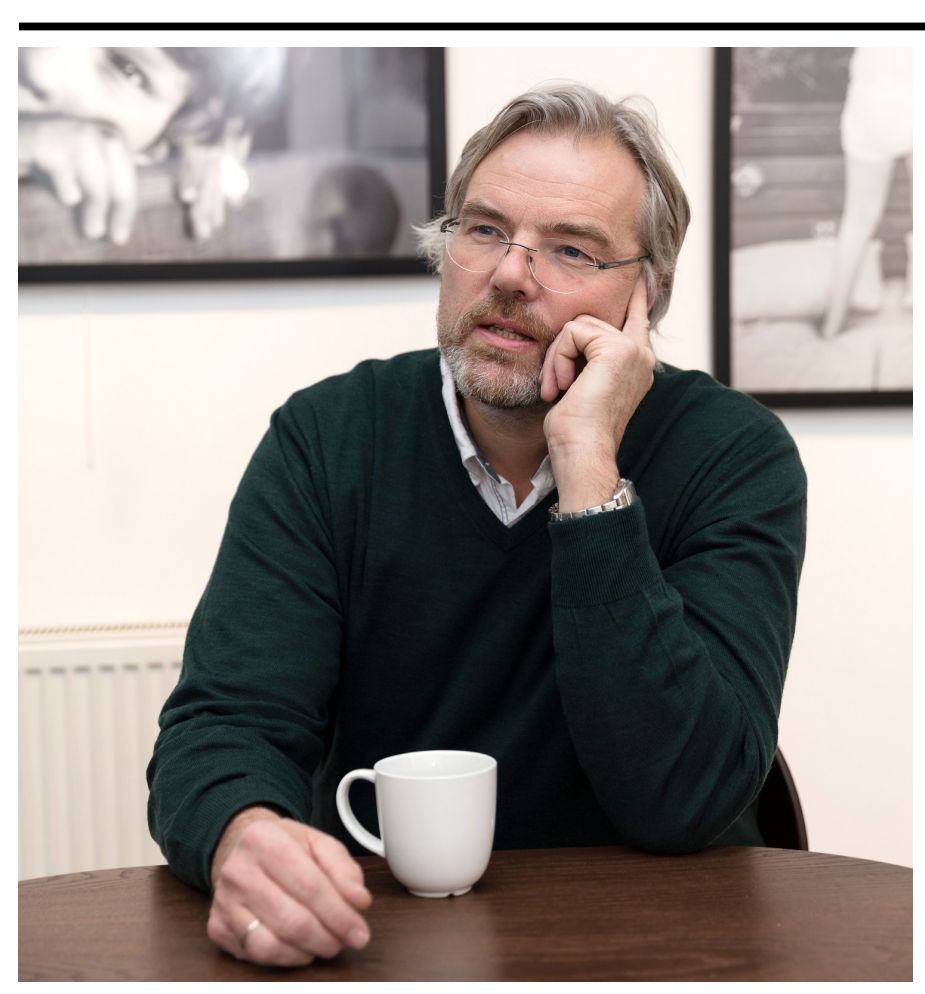

INTERVJU

\section{MARIT TVEITO}

E-post: marit.tveito@me.com

- Medisin trenger ikke alltid å være så «brainy». Nevrolog Magne Bøe er opptatt av å hjelpe «hverdagspasienter» med store plager og lav status. Hans egen hverdag ble snudd på hodet da han og kona fikk et alvorlig sykt barn. Nå er bildene av datterens liv blitt til fotobok og utstilling.

For tre år siden begynte Magne Bøe med et fotoprosjekt som skulle handle om datteren Maria. Hun er yngst av tre barn og fyller $16 \mathrm{i}$ år. Hun har Angelmans syndrom og et mentalt nivå som en ettåring. Vi møtes i galleriet, hvor han gjør de siste justeringene før utstillingen åpner samme kveld. Store portretter og situasjonsbilder i svart-hvitt fyller veggene i Fotografiens hus i Oslo, og fotobøkene ligger klare på et bord.

- Det er litt som en disputas dette, humrer han og forteller at Dagsrevyen nettopp har gjort et intervju til kveldens nyhetssending. Dagbladet har laget et oppslag til helgens magasin. 
Han vil gjerne vise at et annerledes liv med sykdom også kan være et godt liv.

- Jeg har fotografert siden jeg var tenåring, men etter at barna ble større har jeg brukt mer tid på det. Mørkerommet er et kreativt rom og et frirom, ja kall det gjerne grublerom, smiler han. Prosjektet har ikke bare resultert i bilder.

- Boken har gitt meg mulighet for refleksjon. Jeg har sortert tankene om hvordan det har vært å få et sykt barn. Vi går tur flere timer hver lørdag, og siden Maria er uten språk kan det bli litt stille. På et tidspunkt begynte jeg å ta med meg kamera.

\section{Strandveien fjordhotell}

- Hvorfor valgte du å bli lege?

- Jeg vokste opp like ved Blakstad sykehus i Asker. Som barn var jeg nysgjerrig på menneskene som var innlagt ved den psykiatriske avdelingen, og lurte mye på hvordan de hadde det. Da jeg var 19, begynte jeg som pleiemedhjelper der. Jeg ville finne ut av om jeg ville ha et liv innenfor helsevesenet. Det var gleden over å jobbe med mennesker som var utslagsgivende for yrkesvalget, og jeg jobbet der mye av legestudiet.

\section{Magne Bøe}

Født 13. august 1963

Cand.med. Universitetet i Oslo 1992

Spesialist i nevrologi 2002

Overlege ved Nevrologisk avdeling, Sørlandet sykehus, Kristiansand

Avdelingsleder 2006-11

Doktorgrad ph.d. Universitetet i Tromsø 2009

Enhetsleder leger Sørlandet sykehus fra 2016

- Hva slags avdeling jobbet du ved?

- Det var en gammeldags åpen avdeling, slike som ikke finnes i dag. Pasientene kom frivillig og fikk hjelp. Det var folk som strevde, og som kanskje manglet ankerfeste i livet sitt. Så hadde vi noe fint som vi kalte Strandveien fjordhotell. Til jul og påske inviterte vi tidligere pasienter som gjester. De var ikke innlagt i avdelingen for behandling, de var der for omsorg og selskap. Jeg tror det beskyttet mot innleggelser, og så var det en verdighet i det.

Pasientene kom fordi de hadde lyst og fordi de hadde glede av det.

- Nå er det ikke rom for slike tilbud i spesialisthelsetjenesten lenger.

- Jeg tror det er synd, det var en rimelig form for ettervern. Uansett - jeg begynte å studere medisin og så nok for meg en tilværelse som lege på et lite sted hvor alle kjenner alle. Jeg begynte i allmennpraksis, men syntes det ble for mye søkelys på drift, effektivitet og økonomi. Konsultasjonene var korte, og jeg syntes ikke at jeg fikk gjort en grundig nok jobb. Litt tilfeldig begynte jeg ved nevrologen i Kristiansand i 1996 og har i hovedsak vært der siden. I nevrologi er samtalen viktig. Jeg er en "psykiatrisk motivert» nevrolog og har mange smertepasienter. De har ofte hatt psykososiale vanskeligheter og mange utfordringer i livet. Jeg synes kroniske smertepasienter er en neglisjert gruppe. De kommer til helsevesenet med vondt overalt og får en undersøkelse for det mest aktuelle symptomet. Deretter blir de gående fra spesialist til spesialist. Kanskje er det legenes egne ambisjoner som står i veien for den gode behandlingen? Behandling av kroniske smertepasienter krediteres ikke som hjernekirurgi eller hjertekirurgi. Det handler mye om hverdagsmennesker som strever. I allmennpraksis likte jeg ikke å jobbe med hodepinepasienter. Jeg skjønte ikke helt hva jeg skulle gjøre og var alltid litt engstelig for å overse en hjernesvulst. Da jeg begynte i nevrologien, møtte jeg meg selv i døren, og fikk pasienter på poliklinikken som jeg hadde henvist selv. Jeg skjønte at jeg måtte ta tak i utfordringen. Det viste seg å være en takknemlig pasientgruppe. 


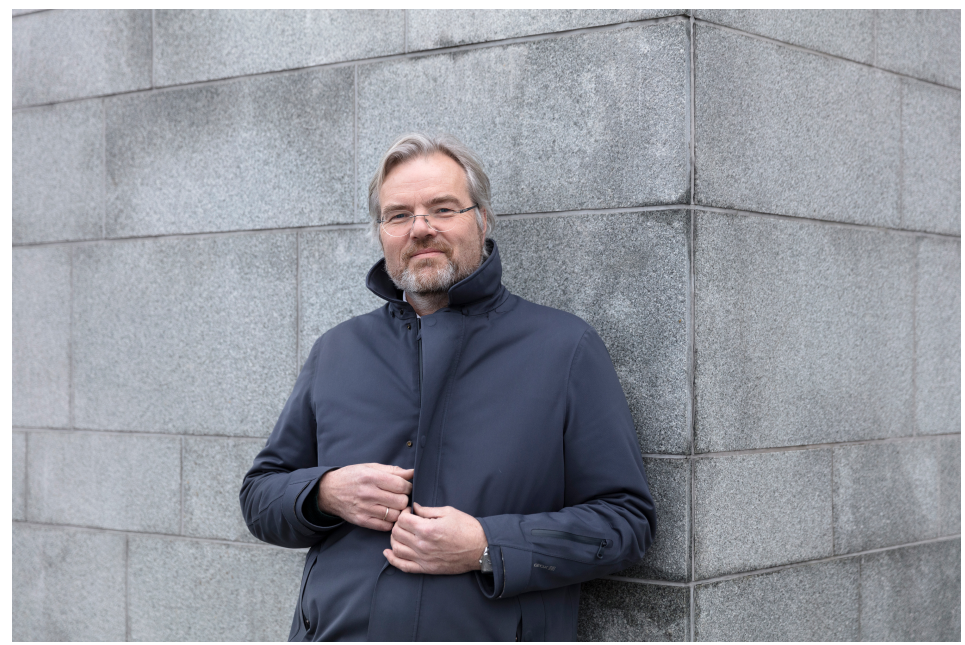

Foto: Christian Tunge

- Hvordan jobber du?

- Jeg spør veldig mye om plager, symptomer, levemåte og vaner, og så spør jeg nesten aldri pasienter om de har psykiske plager. Jeg spør hvordan de sover - og så nøster jeg videre derfra. Hva tenker du på når du ligger i sengen? Så har vi plutselig rullet opp en hel historie som inneholder noe nyttig, og som gjør at vi kan hjelpe. Jeg er også opptatt av å utfordre pasientene til å gå inn i en forpliktende rolle, pasientene må bidra til egen bedring.

- Det høres ut som en terapitime?

- Jo, du kan så si. Det er ikke så «brainy» medisin, men det er engasjert medisin. Det som gir anerkjennelse i legemiljøet, er å tenke en innmari vanskelig tanke, ta en prøve som ingen har hørt om - og få treff. Da stiger du i gradene. Det er fint det, men det er mye hverdagsmedisin som ikke får nok oppmerksomhet. Hvorfor er vi så interessert i det spesielle og sjeldne? Er det også litt for å fremme oss selv? Vi må håndtere de sjeldne tilstandene, det er viktig for disse pasientene, men vi har et stort gross som vi må hjelpe bedre.

\section{Hodepine}

Bøe er nevrolog med hodepine som spesialfelt.

- Jeg har tatt doktorgrad i kronisk hodepine og gått den akademiske veien, men det var av nysgjerrighet. Jeg forsket halve tiden i seks år, de siste årene som avdelingsleder samtidig. Så hadde vi et funksjonshemmet barn på samme tid.

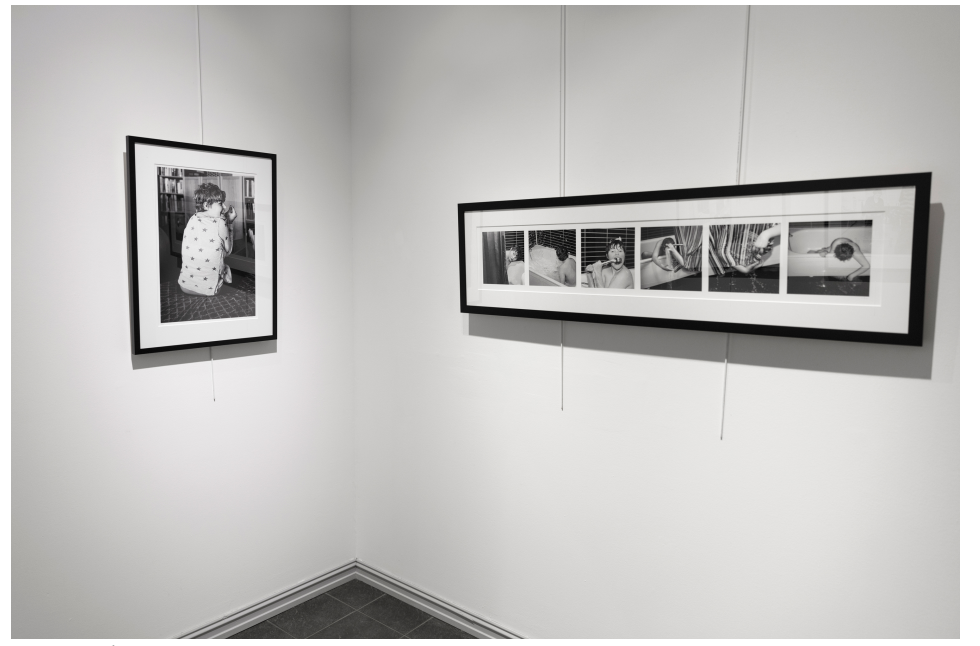

Foto: Christian Tunge

- Det høres ut som mye på en gang?

- Da jeg begynte med doktorgraden, fikk jeg mulighet til å regulere hverdagen halve tiden. 
Forskningen ga meg den fleksibiliteten jeg trengte på hjemmebane. På jobben undersøkte jeg fortsatt hodepinepasienter, men på en litt mer strukturert måte. Så var det interessant å forsøke å finne ut av sammenhenger. Det står fortsatt mye i lærebøker som det ikke er evidens for om hodepinebehandling. Blant annet har det stått at pasienter med medikamentutløst hodepine kunne bruke kortison en periode under avvenningen. Dette ville jeg finne mer ut av. Vi inkluderte 1oo pasienter og dobbeltblindet behandlingen. Det var en helt lokal studie.

- Du lagde en randomisert, kontrollert studie (RCT)?

- Ja, og fant ingen effekt av kortison. Studien gikk rett inn i Neurology på første forsøk. Det var artig. Tenk at de likte en studie fra et lite sykehus som vårt! Jeg hadde hatt god veiledning, en god design, og så var det en klinisk problemstilling som ikke var adressert. Nevrologien består av en femdel hodepinepasienter, men det er få nevrologer som interesserer seg for dette. Jeg tror jeg har bidratt til at flere som har hatt uføretrygd, har startet $i$ arbeid igjen. De trengte hjelp med sine problemer, og da er kanskje det at noen bryr seg, avgjørende.

\section{Å lede leger}

Bøe har hatt flere lederfunksjoner, nå er han enhetsleder.

- Leger er selvstyrte, trives med det, men styrer seg gjerne i litt ulike retninger. Hvis man skal få en avdeling til å fungere, må man bli enig om hvordan man skal gjøre ting. Jeg tror ikke vi snakker nok om hvordan vi jobber sammen, om forventninger vi har til hverandre. Mye kan bidra til at et samhold på en avdeling forstyrres. Det kan være personlige ambisjoner hos noen som gjerne vil nå en posisjon, og så kan det bli et internt hierarki og et klatresystem som er lite hensiktsmessig. Jeg synes vi må komme oss videre og gjøre hverandre gode. Hvis vi lager gode systemer og er gode venner som hjelper hverandre - da gjør vi noe bra for pasientene. Det er godt å komme til et hus som er i orden, enten det er et vanlig hus eller et sykehus.

- Hvordan skal ledelsen bidra?

- Sykehusledere er hyggelige mennesker som vil det beste, men det er alltid noen som mener at vi er dårlig organisert. At hvis vi bare jobber smartere og bruker et eller annet nytt prinsipp, så henter vi frem en ubenyttet ressurs. Det tror jeg ikke noe på. Kravet til resultater $\emptyset$ ker hvert år, samtidig med reduksjoner i budsjettet. Det blir ikke troverdig. Jeg synes det er dumt å ha resultatmål som vi ikke tror på. Jeg kunne ønske meg at vi ikke telte antall konsultasjoner, men heller antall fornøyde pasienter. Skal sluttresultatet leses i et regneark, eller skal det leses i en pasientkontakt som ble bra - for å sette det litt på spissen. Jeg skjønner at man må lede og bruke relevante verktøy, men jeg savner pasientperspektivet. Jeg har ikke fått det til på min arbeidsplass når jeg har fungert som leder, men jeg har tanker om det, og jeg synes det er viktig. Hva slags moderne sykehus skal vi ha, og hva slags helsevesen vil folk ha - vi må spørre om det.

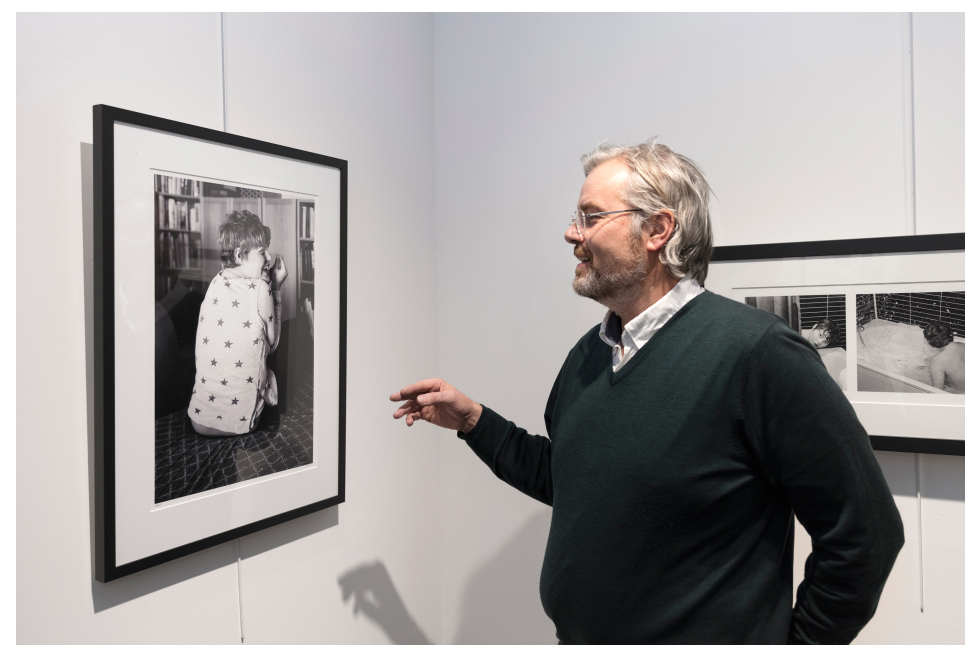


- Hva slags helsevesen tror du vi får?

- Jeg fyller 55 i år og må innse at jeg er en senior på arbeidsplassen. Jeg har hatt privilegiet med å være med på å si ja til nye behandlingsmuligheter. Yngre legers utfordring vil være å si nei, og det har de ikke fått trening i. Det kommer mange nye behandlingsformer i løpet av få år, og det utfordrer oss på etikk, økonomi og kapasitet. Er det riktig at vi i et av verdens rikeste land skal bevilge oss alt mulig og forlenge livene våre med ett til to år, mens store deler av verden kunne fått mye helsehjelp for prisen av det samme. Jeg er ikke sikker på om etikken på dette punktet står støtt. Når alle i hele verden kan se hvordan alle har det, blir vi utfordret. Vi ser nøden, og de som er nødstilte, ser oss. Det må vi klare å ta inn i vår bevissthet, slik at vi tenker annerledes om goder. Vi lever i en verden, ikke bare et land.

Bøe og kona, som jobber som barne- og ungdomspsykiater, hadde drømmer om en stor familie som blant annet skulle reise ut og jobbe med bistand. Planene måtte legges om da Maria ble født.

\section{Et lite barn hele livet}

- Etter noen måneder skjønte vi at hun var annerledes. Først trodde vi det var synet, så skjønte vi at det var mer alvorlig. Etter ett år fikk hun diagnosen. Først var det et sjokk å ha fått et barn som var så hjelpetrengende. Vi tenkte mye på at vårt liv ville forandres helt, og at hun ikke ville få et liv som andre barn. Det var en sorg på vegne av henne, at hun ikke kunne delta i livet som andre. Hun er utelukket fra en rekke ting som vi ønsker for våre barn, og så var det også en sorg at vi måtte forlate våre egne drømmer og planer. De første årene sov hun veldig dårlig. Det var krevende, men vi bestemte oss tidlig for å leve så normalt som mulig. Vi ville være en vanlig familie. Det var nok litt ambisiøst, men vi forsøkte. Vi ville arbeide i full stilling begge to. Ikke fordi vi ikke hadde omsorg for Maria, men vi var redde for at vi skulle ramle ned i et slags hull det ville være vanskelig å komme opp av. Vi tok henne tidlig til vanlig barnehage, etter hvert til en spesialbarnehage. Vi sa fra at vi måtte ha avlastning, allerede fra hun var fire år. Vi følte oss ikke som bra foreldre, men vi innså at det var nødvendig for å passe på de andre barna, og at dette var nødvendig for oss - så vi kunne holde ut med hverandre og dette livet. Jeg tror det var et smart grep. Vi valgte også å bygge om huset en god del da vi skjønte at vi kom til å være mye hjemme. Vi var heldige og hadde et hus som tillot dette, og råd til å gjøre det. At vi begge er leger hjalp oss nok til å være realistiske. Vi visste at det ikke er noe som kan gjøre hennes liv veldig annerledes. Det er ikke noe vi kan hente fra helsevesenet utover vanlig helsetilbud. Kunnskapen om dette gjorde at vi slapp å lete og streve etter mulig behandling. Jeg tror kanskje foreldre får dårlige råd når det gjelder å være hjemme med sine funksjonshemmede barn. De slutter i arbeidet og forlater normaliteten. Jeg tror det er uheldig, selv om de på denne måten tar godt vare på barna. Man kan bli sugd inn i en avhengighetstilværelse hvor alt dreier seg om omsorg og ingen stimuli som voksen. Alle må gjøre sine valg, men jeg tror helsevesenet godt kan råde folk til å bevare et normalt liv i størst mulig grad. Det beskytter og gjør godt for en selv, for familien og barnet man skal hjelpe. Det opplevde vi aldri at noen sa til oss. Jeg tror mange sliter seg ut ved å være hjemme, og til syvende og sist får man mindre å gi. Alle foreldre til funksjonshemmede barn må forberede seg på at andre skal ivareta det. Vi kan ikke pålegge søsken å gjøre dette når vi blir for gamle. Vi håper at de vil ha et godt forhold og vil bry seg om henne, men vi kan ikke pålegge dem den byrden.

- De har ikke ønsket å være en del av fotoutstillingen?

- De ønsker ikke å være så profilerte. Det er greit. De er engasjerte, men de har jo også opplevd det som belastende å ha en syk søster.

- De ville ikke ha med lillesøster på skoleavslutninger?

- Nei, de ville ikke det. Det kunne være sårt for oss, og vi måtte ta noen valg. Skulle vi trumfe gjennom vårt ønske om at begge foreldrene skulle delta på skoleavslutninger, eller skulle vi 
respektere barnas ønske om å holde Maria borte? Vi grunnet over det og ble enige om å respektere barnas ønsker. De har en stor utfordring i livet som de ikke har valgt, og som de ikke kommer bort fra. De få gangene de ber om å bli skjermet, må vi ha respekt for det og heller leve med at vi ikke får være med.

- Det blir mye oppmerksomhet rundt den syke, går det ut over de friske?

- Familier som vår har en stor belastning, og hvis man ikke tar grep, risikerer man at hele familien blir syk. Vi er ikke supermennesker og har våre svakheter, men vi greier oss. Kanskje fordi vi raskt så og sa hva vi trengte, og at vi ville stå i jobb. Det er ikke alltid et ekteskap overlever at drømmene må endres betraktelig. Jeg tror at vi var heldige med å finne noen løsninger som fungerte godt.

I fotoprosjektet han satte i gang, hadde han nytte av sin vitenskapelige erfaring.

- Jeg skrev en protokoll, lagde en tidsplan og ga prosjektet struktur på den måten. Jeg ville vise hennes liv. Jeg har bare brukt gammeldags film og fremkalling. Jeg synes det passer med langsom fotografering hvor man må «vente ut» motivet og ikke bruke opp rullen.

- Hva tenker du om at hun ikke kan samtykke til fotografering og publisering?

- Det har vi snakket mye om. Vi har vært opptatt av at bildene skal ha en verdighet og har valgt nøye ut hva vi vil vise og ikke vise.

- Hva skal du fotografere nå?

- Neste prosjekt handler om de nære ting- det å se hverdagen rundt oss med de visuelle pussighetene som finnes. Kanskje skal jeg også fotografere Maria når hun flytter over i egen bolig. Jeg har lyst til å gjøre mer av de tingene som gjør meg godt. Jeg synes foto gjør meg oppmerksom på alt rundt meg på en måte som beriker livet mitt. Og kanskje får noen andre glede av å få se det samme.

Publisert: 5. mars 2018. Tidsskr Nor Legeforen. DOI: 10.4045/tidsskr.18.oo6o

(C) Tidsskrift for Den norske legeforening 2020. Lastet ned fra tidsskriftet.no 